\title{
PEMIKIRAN YUSUF QARDHAWI MENGENAI ZAKAT SAHAM DAN OBLIGASI
}

\author{
Ririn Fauziyah \\ Fakultas Syari'ah UIN MALIKI Malang \\ Telepon: 085755593982 \\ Email: ririn_reefa@yahoo.com
}

\begin{abstract}
Abstrak
Ijtihad in the field of zakat has been started since the launch of Yusuf Qardhawi writings, Fiqh alZakâh. Zakat which has been traditionally interpreted, broken down by Yusuf Qaradawi to create new categories, namely zakat stocks and bonds. The objectif of research is to finding Yusuf Qardhawi's thought about zakat stocks and bonds. This type of research is study of literature, and the research are descriptive. Qardhawi's opinion, factories and buildings can be analogous to agricultural land, so that zakat must be paid $10 \%$ or $5 \%$ of net revenues. Meanwhile for trading company, its zakat taken from its appropriate at the prevailing market price plus a profit. Bond issued zakat taken when bonds were already in the hands of the owner for a year or more. The bonds that bring interest, such as obligatory zakat issued trading, must be paid $2.5 \%$.

Ijtihad dalam bidang zakat telah dimulai sejak Yusuf Qardhawi meluncurkan karya tulisnya, Fiqh alZakâh. Zakat yang selama ini dimaknai secara tradisional, didobrak oleh Yusuf Qardhawi dengan membuat kategori baru, yaitu zakat saham dan obligasi. Tujuan penelitian untuk mengetahui pemikiran Yusuf Qardhawi mengenai zakat saham dan obligasi. Jenis penelitian adalah penelitian kepustakaan dan sifatnya penelitian deskriptif. Menurut Qardhawi, pabrik dan gedung dapat dianalogikan dengan tanah pertanian, sehingga harus dikeluarkan zakatnya $10 \%$ atau 5\% dari pendapatan bersih. Sedangkan perusahaan perdagangan, zakatnya diambil dari sahamnya sesuai harga yang berlaku di pasar ditambah keuntungan. Zakat obligasi wajib dikeluarkan bila obligasi itu sudah berada di tangan pemilik selama satu tahun atau lebih. Obligasi yang mendatangkan bunga, wajib dikeluarkan zakatnya seperti zakat perdagangan, yaitu sebesar 2.5\%.
\end{abstract}

Kata kunci: Pemikiran Yusuf Qardhawi, Zakat Saham dan Obligasi.

Dalam kehidupan bermasyarakat baik pada masa lalu maupun pada masa sekarang, sering dijumpai adanya jurang pemisah antara si kaya dan si miskin. Hubungan kaya-miskin ini dalam syari'at Islam dilandaskan pada firman Allah dalam surat alDzâriyât:19 yang berbunyi:



"Dan pada harta-harta mereka ada hak untuk orang miskin yang meminta dan orang miskin yang tidak mendapat bagian".

Islam sebagai sebuah ajaran menghendakiadanya perhatian pada mereka-mereka yang berada dalam jurang kemiskinan. Keinginan Islam untuk membantu dan mengangkat mereka dari jurang kemiskinan tersebut diaplikasikan dengan ditunaikannya zakat dalam agama Islam.

Zakat merupakan ajaran yang melandasi tumbuhkembangnya sebuah kekuatan sosial ekonomi umat
Islam. Kerangka terminologi zakat menumbuhkan pemahaman diantaranya yaitu : Pertama, dalam bentuk pengertian tauhid, zakat dilaksanakan berdasarkan petunjuk Allah SWT, sehingga tujuan pokok pelaksanaannya adalah untuk mendekatkan diri kepada Tuhan yang Maha Kuasa, beriman dan ikhlas beramal dalam usaha beribadah kepada Tuhan; Kedua, dalam pengertian hukum, zakat adalah hukum Tuhan yang sesuai dengan hukum yang berlaku dalam alam semesta agar manusia dapat hidup saling mencintai dan tolong-menolong yang didasari rasa kasih sayang sesama makhluk Tuhan; Ketiga, dalam pengertian akhlak, zakat adalah isi dari penjelmaan budi manusia yang mulia, pelaksanaan kehendak rasa antara si kaya dan si miskin, dan sekaligus sumber praktik persamaan dan persaudaraan kemanusiaan dalam aspek kehidupan sosial; Keempat, dalam pengertian sosial, zakat tumbuh untuk menyamakan dan mempersaudarakan seluruh umattemlanubia dalam masyarakat kemanusiaan 
yang satu, yang berwujud pengorbanan benda dalam hidup bertolong-tolongan; Kelima, dalam pengertian ekonomi, zakat meninggikan hasrat produksi modern bagi keperluan hidup, melancarkan jalan distribusi dan menstabilitaskan konsumsi dalam kehidupan masyarakat tanpa ada jurang pemisah antara si kaya dan si miskin.

Pelaksanaan zakat telah diwajibkan kepada semua orang muslim karena merupakan bagian dari rukun Islam. Kewajiban tersebut berupa pengeluaran sejumlah harta tertentu yang terselip dalam kekayaan yang dimiliki oleh setiap pribadi muslim yang diwajibkan oleh Allah untuk disedekahkan kepada orangorang yang berhak setelah mencapai nishảb dan haul dengan satu tujuan sosial sebagai salah satu alternatif solusi pengentasan kemiskinan umat.

Untuk mengilustrasikan betapa pentingnya kedudukan zakat, al-Qur'an dengan jelas menyebutkan kata zakat (al-zakảh) yang dirangkaikan dengan kata shalat (al-shalảh) sebanyak 72 kali. Menurut hitungan Ali Yafie, hal ini dapat diinterpretasikan bahwa penunaian zakat memiliki urgensi yang sebanding dengan pendirian shalat.

Seiring perkembangan zaman, berkembang pula pemahaman para tokoh Islam dalam memahami makna dan objek zakat. Tidak ada ayat yang menunjukkan adanya pembatasan sumber-sumber zakat. Semuanya ditampilkan dalam bentuk lafadh ảm yang mencakup seluruh individu. Berdasarkan keumuman zakat tersebut, maka semua hasil usaha atau hasil bumi dikenakan kewajiban zakat termasuk di dalamnya zakat saham dan obligasi.

Saham dianggap sebagai bagian prosentatif dari modal usaha, Oleh sebab itu harus dikeluarkan zakatnya oleh para pemegang saham masing-masing. Namun, pihak perusahaan bisa mengeluarkan zakatnya sebagai perwakilan mereka kalau itu ditegaskan dalam peraturan dasar mereka, atau bisa juga diserahkan kepada para pemilik saham untuk dikeluarkan zakatnya.

Mengenai kewajiban zakat saham dan obligasi para ulama telah sepakat untuk mengeluarkan zakatnya karena saham dan obligasi adalah merupakan harta kekayaan dan setiap harta kekayaan ada hak orang lain di dalamnya (zakat, infak, dan sedekah). Dalam penentuan zakatnya para ulama berbeda pendapat.

Sebagian ulama seperti Syekh Abdur Rahman Isa, memandang bahwa zakat baru bisa ditentukan setelah melihat apakah saham itu dikeluarkan atau dimiliki seseorang untuk industri murni (tidak melakukan ke- giatan dagang), seperti hotel, pengangkutan (udara, darat, laut), pabrik, dan usaha-usaha lain yang mengadakan kegiatan dagang.

Sebagian ulama lain seperti Abu Zahrah, Abdurrahman Hasan dan Abdul Wahab Khallaf memandang sama antara saham dan obligasi dengan barang dagangan dan merupakan harta kekayaan. Mereka juga mengatakan bahwa saham dan obligasi itu sebagai surat berharga yang dapat diperjualbelikan.

Saham memberikan keuntungan sesuai dengan keuntungan perusahaan atau bank, yang besarnya tergantung pada keberhasilan perusahaan atau bank itu, tetapi juga menanggung kerugiannya. Sedangkan obligasi memberikan keuntungan tertentu (bunga) atas pinjaman tanpa bertambah atau berkurang.

Selama perusahaan tersebut tidak memproduksi barang-barang atau komoditas-komoditas yang dilarang, maka saham menjadi salah satu objek atau sumber zakat. Sedangkan obligasi sangat tergantung kepada bunga yang termasuk kategori riba. Namun yang menarik adalah bahwa sebagian ulama, walaupun sepakat akan haramnya bunga, tetapi mereka tetap menyatakan bahwa obligasi adalah suatu objek atau sumber zakat dalam perekonomian modern ini

Muhammad Abu Zahrah menyatakan bahwa jika obligasi itu kita bebaskan dari zakat, maka akibatnya orang lebih suka memanfaatkan obligasi dari pada saham. Dengan demikian orang akan terdorong untuk meninggalkan yang halal dan melakukan yang haram. Dan juga bila ada harta haram, sedangkan pemiliknya tidak diketahui, maka ia disalurkan kepada sedekah.

Dari sini peneliti melihat perlunya melakukan penelitian mengenai pemikiran Yusuf Qardhawi tentang zakat saham dan obligasi karena Yusuf Qardhawi sendiri merupakan ulama yang mengklaim bahwa dirinya sebagai orang yang menempuh jalan tengah (moderat) dalam segala hal. Selain itu, zakat saham dan obligasi masih menjadi perdebatan antar ulama baik mengenai waktu mengeluarkan zakatnya, kadar ataupun mengenai nisabnya. Banyak dari para pemilik saham yang belum mengetahui dan memahami tentang kewajiban zakat saham dan obligasi itu sendiri. Sehingga banyak masyarakat pemilik saham yang belum mengeluarkan zakat atas saham dan obligasi yang dimiliki. Dalam penelitian ini, peneliti juga menganggap perlu mengetahui lebih jauh mengenai biografi dan latar belakang pendidikan Yusuf Qardhawi sehingga dapat melahirkan pemikiran baru mengenai zakat saham dan obligasi.

\section{Created with \\ (n) nitro $^{\text {PDF }^{\prime}}$ professional}




\section{METODE}

Jenis penelitian ini termasuk jenis kepustakaan (Library Research). Sedangkan berdasarkan sifatnya, penelitian ini dikategorikan sebagai penelitian deskriptif. Penelitian deskriptif dimaksudkan untuk memberikan data seteliti mungkin tentang manusia, keadaan atau gejala-gajala lainnya. Dalam hal ini adalah kehidupan dan latar belakang pendidikan Yusuf Qardhawi serta menganalisis terhadap pemikiran Yusuf Qardhawi mengenai zakat saham dan obligasi.

Metode pengumpulan data yang digunakan dalam penelitian ini adalah penelaahan naskah atau studi kepustakaan. Dalam metode pengumpulan data jenis ini data bisa didapatkan dari catatan pribadi, surat pribadi, buku harian, laporan kerja, notulen rapat, catatan kasus, rekaman kaset, video, foto dan lain sebagainya .

Data-data dalam penelitian ini diperoleh dari buku-buku yang menjadi bahan primer yakni "Fiqh Zakat" karangan Yusuf Qardhawi dan buku-buku lain yang membahas tentang pemikiran Yusuf Qardhawi mengenai zakat saham dan obligasi, diikuti datadata dari buku-buku sekunder yang menjelaskan dan berkaitan dengan zakat saham dan obligasi.

Dalam menganalisis data-data tersebut, peneliti menggunakan analisis isi (content analysis), yaitu menggambarkan secara umum tentang obyek yang akan diteliti. Analisis ini dilakukan dengan melihat dan menelaah pemikiran Yusuf Qardhawi mengenai zakat saham dan obligasi.

\section{HASIL DAN PEMBAHASAN}

\section{Hasil}

Masih terdapat perbedaan pendapat antara ulama yang satu dengan lainnya dalam menyikapi tentang zakat saham dan obligasi. Berikut pandangan ulama tetang zakat saham dan obligasi.

Golongan ulama yang pertama, seperti Syekh Abdur Rahman Isa, memandang bahwa zakat saham bisa ditentukan setelah melihat apakah saham tersebut dikeluarkan atau dimiliki seseorang untuk industri murni (tidak melakukan kegiatan dagang), seperti hotel, pengangkutan (udara, darat, laut), pabrik, dan usaha-usaha lain yang mengadakan kegiatan dagang.

Dalam masalah ini, yang wajib dikelurkan zakatnya adalah keuntungan yang diperoleh dari usahausaha tersebut, sama halnya seperti zakat pertanian yang dikeluarkan adalah hasil bukan tanahnya. Dengan demikian, zakatnya pun ada kemungkinan 10\% atau $5 \%$ dari keuntungan bersih perusahaan. Untuk menentukan seberapa besar zakatnya sangat bergan- tung kepada berat ringannya, atau besar tidaknya biaya yang dikeluarkan.

Sebagian ulama kontemporer berpendapat bahwa saham tidak dipandang menurut jenis perusahaannya sehingga saham satu perusahaan berbeda dari saham perusahaan yang lain, akan tetapi saham itu dipandang satu jenis dan mempunyai satu hukum pula tanpa memandang perusahaan apa yang menerbitkannya.

Ulama-ulama besar seperti Abu Zahrah, Abdurrahman Hasan, dan Abdul Wahab Khallaf berpendapat bahwa saham dan obligasi adalah harta yang diperjualbelikan karena pemiliknya memperjualbalikannya dan dari perniagaan tersebut pemilik memperoleh keuntungan persis seperti pedagang dengan barang dagangannya.

Golongan Syafi'iyah, Hanafiyah dan Malikiyah mewajibkan pungutan zakat pada uang kertas dan surat-surat berharga lainnya karena uang kertas, rekening bank dan surat-surat berharga lainnya disamakan dengan emas dan perak, karena sama-sama memiliki fungsi sebagai alat tukar menukar barang dan merupakan harta benda yang bernilai ekonomis dan berkembang, yaitu mengandung unsur maliyah dan unsur nama' atau istinma'. Sedangkan menurut golongan Hanabilah, tidak wajib zakat pada harta tersebut karena bukan merupakan emas dan perak, sedangkan yang diwajibkan zakat adalah emas dan perak. Adapun mengenai zakat obligasi, Malik dan Abu Yusuf mengemukakan bahwa zakatnya dibayar setelah mencapai satu tahun pada pemegangnya.

Golongan kedua antara lain seperti Abu Zahrah, Abdur Rahman Hasan, dan Abdul Wahab Khallaf mengatakan bahwa saham dan obligasi adalah surat berharga yang bisa diperjualbelikan sehingga dapat disamakan dengan barang dagangan dan merupakan harta kekayaan.

Bila saham dan obligasi dianggap sama dengan barang dagangan, maka zakatnya juga disamakan dengan barang dagangan, yaitu sebesar 2,5\%.

Di dalam buku "Fiqh dan Manajemen Zakat di Indonesia" disebutkan bahwa zakat saham dan obligasi dianalogikan pada zakat perdagangan, baik nisab maupun ukurannya, yaitu senilai 85 gram emas dan zakatnya sebesar $2,5 \%$.

Mengenai kewajiban zakat saham dan obligasi, al-Qur'an tidak menyebutkan secara jelas namun kita dapat melihat kembali dalil-dalil yang telah dikemukakan terdahulu mengenai zakat seperti yang tercantum dalam surat Al-Taubah ayat 103 dan surat al-Dzarivat ayat 19 yang berbunyi_sebagai berikut: 


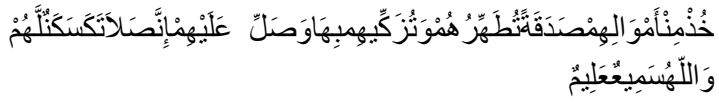

"Ambillah zakat dari sebagian harta mereka, dengan zakat itu kamu membersihkan dan mensucikan mereka dan mendoalah untuk mereka. Sesungguhnya doa kamu itu (menjadi) ketenteraman jiwa bagi mereka. dan Allah Maha mendengar lagi Maha Mengetahui".

Sedangkan surat al-Dzariyat ayat 19 adalah:

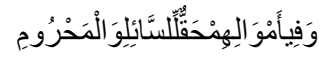

"Dan pada harta-harta mereka ada hak untuk orang miskin yang meminta dan orang miskin yang tidak mendapat bagian".

Sebagaimana landasan hukum bagi harta-harta dalam perekonomian lainnya, landasan kewajiban zakat saham dan obligasipun diambil dari keumuman ayat tentang harta-harta yang wajib dizakati.

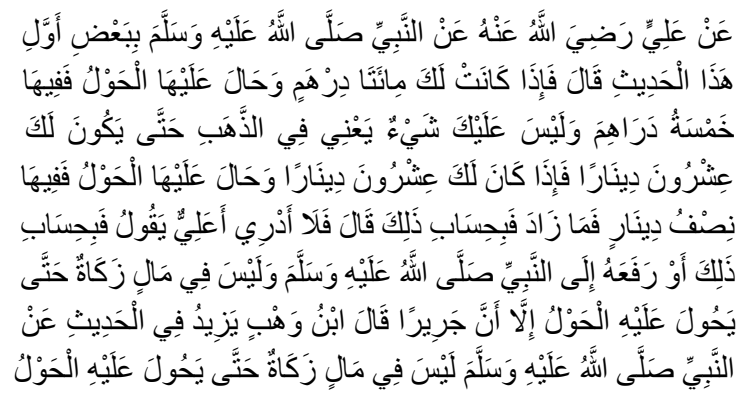

Nabi SAW bersabda, "Sayidina Ali telah meriwayatkan bahwa Nabi SAW telah bersabda: "apabila kamu mempunyai 200 dirham dan telah cukup haul (genap satu tahun) diwajibkan zakatnya 5 dirham dan tidak diwajibkan mengeluarkan zakat (emas) kecuali kamu mempunyai 20 dinar. Apabila kamu mempunyai 20 dinar dan telah cukup haulnya, diwajibkan zakatnya setengah dinar. Demikian juga ukurannya jika nilainya bertambah dan tidak diwajibkan zakat bagi sesuatu harta kecuali genap satu tahun.

Berdasarkan keterangan di atas, zakat saham dan obligasi dianalogikan pada zakat perdagangan, baik nishab maupun ukurannya, yaitu senilai 85 gram emas dan zakatnya sebesar 2,5\%. Sementara itu muktamar internasional pertama tentang zakat (Kuwait, 29 Rajab $1404 \mathrm{H}$ ) menyatakan bahwa jika perusahaan telah mengeluarkan zakatnya sebelum dividen dibagikan kepada pemegang saham, maka pemegang saham tidak perlu lagi mengeluarkan zakatnya. Jika belum mengeluarkan, maka pemegang sahamlah yang berkewajiban mengeluarkan zakatnya.

Bila si pemilik bermaksud memperjualbelikan sahamnya, maka volume zakat yang wajib dikeluarkan ialah sebesar 2,5\% dari harga pasaran yang berlaku pada waktu kekayaan mencapai haul seperti komoditas dagang yang lain. Jika si pemilik hanya mengambil keuntungan dari laba tahunan saham itu, maka cara pembayaran zakatnya sebagai berikut: Pertama, jika ia bisa mengetahui melalui perusahaan yang mengeluarkan saham atau pihak lain, nilai setiap saham dari total kekayaan perusahaan yang wajib dizakati, maka ia wajib membayar zakatnya sebesar 2,5\% dari nilai saham itu. Kedua, jika ia tidak dapat mengetahuinya, maka ia harus menggabungkan laba saham tersebut dengan kekayaan yang lain dalam penghitungan haul dan nishab kemudian membayar zakatnya sebesar $2,5 \%$.

\section{Contoh cara menghitung zakat saham:}

Nyonya Fatimah memiliki 500.000 lembar saham PT Abdi Ilahi Rabbi. Harga nominal Rp. 5.000,00/lembar. Pada akhir tahun buku, setiap lembar saham memperoleh deviden Rp.300,00. Bagaimana perhitungan zakatnya?

\section{Jawabannya:}

Nilai saham (book value) (500.000 x Rp. $5.000,-)$ $=$ Rp. $2.500 .000 .000,00$. Deviden $(500.000 \times$ Rp. $300,-)$ $=$ Rp. 150.000.000,00. Total Rp. 2.650.000.000,00. Maka zakat yang harus dikeluarkan adalah: $2,5 \% \mathrm{x}$ Rp. $2.650 .000 .000,00=$ Rp. $66.250 .000,00$.

Mengenai zakat obligasi, terdapat tiga perbedaan pendapat yaitu: Pertama, pendapat yang mengatakan bahwa zakat tidak wajib dikenakan atas obligasi dan bunga yang diperoleh, karena mengandung unsur riba yang diharamkan syara'. Oleh karenaitu mengeluarkan zakat dari sesuatu yang haram hukumnya tidak sah. Kedua, pendapat ini agak moderat, yaitu mengatakan bahwa meskipun mengandung unsur riba namun tidak berarti pemilik obligasi dibebaskan dari zakat. Kepemilikan si pembeli atas obligasi tersebut sah secara syara' dan obligasi tersebut merupakan harta produktif yang dapat diperjualbelikan dan memberikan keuntungan bagi pemiliknya. Zakat wajib dikeluarkan atas harga atau nilai dari obligasi itu sendiri dan bukan dari bunganya. Besarnya suku zakat adalah 2,5 $\%$ yang dikeluarkan setiap akhir tahun. Ketiga, pendapat yang dikemukakan oleh Wahbah al-Zuhaili bahwa zakat wajib atas obligasi dan bunganya. Mekanisme pengeluaran zakatnya adalah dengan menggabungkan nilai keduanya pada waktu jatuh tempo dan dikeluarkan jika telah mencapai haul dan nisabnya yang dianalogikan dengan zakat pertanian dan perkebunan ${ }^{2}$ with

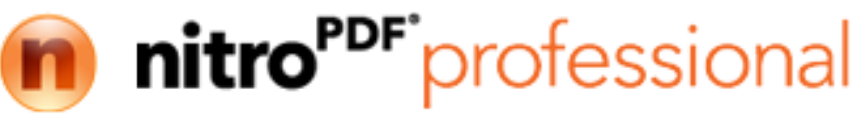




\section{Pembahasan}

Qardhawi dikenal sebagai ulama fiqh yang bertumpu pada Fikih Realitas, yaitu fikih yang didasarkan pada pertimbangan antara mashlahah dan mafsadah. Realitas di sini juga bermakna hendaknya seseorang hidup dengan kondisi dan realitas yang ada.

Pemikiranal-Qardhawidalambidangkeagamaan dan politik banyak diwarnai oleh pemikiran Syekh Hasan al-Banna. Ia sangat mengagumi Syekh Hasan al-Banna dan menyerap banyak pemikirannya. Baginya Syekh Hasan al-Banna merupakan ulama yang konsisten mempertahankan nilai-nilai agama Islam, tanpa terpengaruh oleh paham nasionalisme dan sekularisme yang diimpor dari barat atau dibawa oleh kaum penjajah ke Mesir dan dunia Islam. Mengenai wawasan ilmiyahnya, al-Qardhawi banyak dipengaruhi oleh pemikiran ulama-ulama al-Azhar.

Adapun faktor-faktor penunjang moderasi alQardhawi adalah: Pertama, penggabungan antara fikih dan hadis. Sesungguhnya Syeikh al-Qardhawi telah mampu memadukan antara fikih dan hadits maupun menggabungkan antara atsar dan nazhar (rasio) dalam menyelesaikan berbagai masalah yang dihadapinya. Pada hakikatnya kedua Ilmu tersebut saling membutuhkan. Sebab hadits dalam posisinya sebagai sumber sebenarnya adalah pokok, sedangkan fikih dalam posisinya sebagai bangunan adalah laksana cabang. Kedua, Mengambil pendapat dari generasi awal Islam. Syeikh al-Qardhawi mengambil semua hal yang baik dari mana saja datangnya. Namun, dia selalu berkonsentrasi dan memfokuskan diri pada fikih shahabat dalam setiap bahasan dan masalah yang dihadapi. Sebab para sahabat adalah generasi yang di zamannya wahyu turun. Kemudian setelah itu beliau akan mengambil pendapat generasi tabi'in, dan barulah mengambil dari generasi orang-orang setelah mereka. Selanjutnya mengambil pendapat generasi setelah tabi'ut tabi'in yang tidak berlebihlebihan dan ekstrim. Ketiga, Menggabungkan antara salafiyah dan tajdid. Dalam hal ini tidak ada saling menafikan antara salafiyah dan tajdid, sebab salafiyah selalu memperbaharui dirinya untuk bisa menyesuaikan dengan zaman dan tidak selalu berada dibawah bayang-bayang masa lalu. Sesungguhnya yang ada pada masa lalu itu dimodifikasi dengan spirit masa kini dan sarana-sarananya. Keempat, mengedepankan yang kulli atas yang juz-i. Beliau tidak akan membahas masalah-masalah yang sifatnya furu'iyyah yang jauh dari pokok-pokok dan pondasi Islam serta prinsip-prinsipnya yang besar. Seperti: hukuman mati bagi seorang muslim yang membunuh kafir dzimmi. Kelima, penggabungan antara mengikuti nash dan memperhatikan syari'ah. Al-Qardhawi selalu mengikat pendapat-pendapatnya dengan nash dari al-Qur'an dan Sunnah yang semuanya berada di bawah koridor maksud syari'ah (legal objektif). Sebab syari'ah yang Allah turunkan pasti memiliki maksud dan Illat tertentu. Sebagai contoh yaitu: diperbolehkannya perjalanan seorang wanita yang tidak disertai mahrảm. Keenam, pembedaan antara variabel zaman dan prinsip-prinsip Islam. Salah satu penunjang kemoderatan al-Qardhawi adalah kemampuannya dalam membedakan antara suatu hal yang prinsip (yang tetap) dan yang berubah dalam syara'. Beliau bahkan mampu menggabungkan antara keduanya.

Selain sebagai ulama yang terkenal sangat memegang teguh sikap moderasi, Yusuf Qardhawi sangat menekankan peran penting ijtihad pada masa sekarang. Qardhawi memberikan tawaran tiga alternatif dalam berijtihad, yakni ijtihad intiqa ' $i$, ijtihad insya' $i$ dan ijtihad integrasi antara keduanya.

Ijtihad intiqả'i atau tarjih yaitu memilih satu pendapat dari beberapa pendapat terkuat yang terdapat pada khazanah fikih Islam yang penuh dengan fatwa dan keputusan hukum. Ijtihad yang diserukan di sini meliputi pengadaan studi komparatif terhadap pendapat-pendapat ulama, meneliti kembali dalildalil yang dijadikan sandaran, sehingga pada akhirnya dapat dipilih pendapat yang terkuat dalil dan alasannya sesuai dengan kaidah tarjih.

Ijtihad insyả'i yaitu pengambilan konklusi hukum baru dari suatu persoalan yang belum pernah dikemukakan oleh ulama terdahulu, atau cara seorang mujtahid kontemporer untuk memiliki pendapat baru dalam suatu masalah yang belum terdapat dalam pendapat ulama salaf. Bisa juga, ketika para pakar fikih terdahulu berselisih sehingga termaktub pada dua pendapat, maka mujtahid masa kini memunculkan pendapat ketiga.

Integrasi antara ijtihad intiqả'i dan insyả'i. Di antara bentuk ijtihad kontemporer adalah ijtihad integratif antar ijtihad intiqa'i dan insya'i, yaitu memilih pendapat para ulama terdahulu yang dipandang lebih relevan dan kuat, kemudian dalam pendapat tersebut ditambah unsur-unsur ijtihad baru.

Al-Qardhawi terkenal sebagai salah seorang yang sangat berpegang teguh pada sikap moderasi, baik dalam bidang pemikiran, fikih, ataupun dakwah. Pengakuan ini bukan saja datang dari kalangan Islamis, namun juga dari orang-orang non-muslim. Diantaranya yaitu Syeikh Muhammad al-Ghazali, Dr. 
Muhammad Imarah dan lain-lain.

Sikap moderat yang diambil Yusuf Qardhawi bersumber dari al-Qur'an dan Sunnah. Karena Islam sendiri adalah agama moderat, dan karakter umat Islam adalah umat moderat. Hal ini sesuai dengan apa yang tercantum dalam beberapa ayat diantaranya surat al-Baqarah: 143, ar-Rahman: 7-9, dan al-A'raaf: 31 dimana ayat-ayat tersebut memerintahkan kita agar bersikap moderat. Selain dari beberapa ayat di atas pada kehidupan Rasulullah juga dipenuhi dengan sikap dan seruan kepada sikap moderat.

Selain sikap moderasi yang dimiliki, Yusuf Qardhawi juga sangat menekankan tentang peran penting ijtihad pada masa sekarang. Sehingga beliau sering menyerukan untuk melakukan ijtihad terhadap masalah-masalah yang dianggap perlu dilakukan ijtihad. Di antara masalah-masalah yang dianggap perlu dilakukan ijtihad adalah mengenai masalah saham dan obligasi. Dalam hal ini Yusuf Qardhawi menggunakan ijtihad insya' $i$ Yaitu mengambil konklusi hukum baru dari suatu persoalan yang belum pernah dikemukakan oleh ulama terdahulu, atau cara seorang mujtahid kontemporer untuk memiliki pendapat baru dalam suatu masalah yang belum terdapat dalam pendapat ulama salaf. Bisa juga, ketika para pakar fikih terdahulu berselisih sehingga termaktub pada dua pendapat, maka mujtahid masa kini memunculkan pendapat ketiga.

Zakat saham dan obligasi sebenarnya mulai dikenal pada zaman modern akhir-akhir ini. Saham dan obligasi dianggap sebagai harta kekayaan yang wajib dizakati karena kedua benda tersebut sama-sama memiliki nilai ekonomi. Disamping bernilai ekonomi, saham dan obligasi merupakan harta yang dapat memberikan pemasukan yang cukup tinggi jika dibandingkan dengan pertanian atau perdagangan. Namun, para ulama berbeda pendapat mengenai kewajiban mengeluarkan zakatnya.

Menurut Yusuf Qardhawi saham adalah hak pemilikan tertentu atas kekayaan suatu perseorangan terbatas atau atas penunjukkan atas saham tersebut. Sedangkan obligasi adalah perjanjian tertulis dari bank, perusahaan, atau pemerintah kepada pembawanya untuk melunasi sejumlah pinjaman dalam masa tertentu dengan bunga tertentu pula. Beliau membedakan saham dan obligasi sebagai berikut: a) Saham merupakan bagian kekayaan bank atau perusahaan sedangkan obligasi merupakan pinjaman kepada perusahaan, bank, atau pemerintah. b) Saham memberikan keuntungan sesuai dengan keuntungan perusahaan atau bank yaitu sesuai dengan keberhasilan perusahaan atau bank tersebut, dan me- nanggung kerugian yang di alami bank atau perusahaan. Sedangkan obligasi memberikan keuntungan atas pinjaman tanpa bertambah atau berkurang. c) Pembawa saham dianggap sebagai pemilik sebagian perusahaan dan bank sebesar nilai saham yang dimiliki, sedangkan pembawa obligasi adalah pemberi hutang atau pinjaman kepada bank atau perusahaan, pemerintah. d) Saham dibayar dari keuntungan bersih perusahaan atau bank sedangkan obligasi dibayar pada waktu tertentu.

Selain memiliki perbedaan keduanya juga memiliki beberapa persamaan yaitu: a) Antara saham dan obligasi sama-sama memiliki harga tertulis, yaitu harga waktu diterbitkan, dan harga pasar yang tergantung pada surat-surat berharga. b) Keduanya digunakan sebagai alat dalam bertransakasi untuk memperoleh keuntungan seperti jual beli. c) Harganya terpengaruh oleh keadaan politik dan ekonomi suatu Negara, pusat perdagangannya, dan keberhasilan perusahaan dan besar keuntungan nyata saham serta besar bunga obligasi, bahkan dipengaruhi oleh situasi internasional seperti perang, damai dan sebagainya.

Dari pemaparan di atas, jelaslah bahwa menerbitkan, memiliki, menjual, membeli, dan mentransaksikannya diperbolehkan, selama kegiatan dari perusahaan tersebut tidak mengandung kegiatan yang haram, seperti memproduksi, menjual dan memperdagangkan minuman keras, atau transaksi perusahaan itu dilakukan dengan memungut riba, baik meminjam maupun meminjamkan, dan sebagainya.

Menurut Yusuf Qardhawi perbedaan pendapat mengenai kewajiban zakat saham dan obligasi tersebut terbagi menjadi dua pendapat yaitu:

Pendapat pertama: Para ulama seperti Syeikh Abdul Rahman Isa menyatakan bahwa zakat saham dan obligasi dapat dikeluarkan zakatnya apabila telah diketahui jenis perusahaan yang mengeluarkan saham dan obligasi tersebut. Apakah perusahaan tersebut merupakan perusahaan industri, perdagangan, atau kombinasi dari keduanya. Dalam bukunya $a l-M u$ 'ảmalah al-Hadithah wa Ahkamuhả, Syeikh Abdul Rahman Isa mengemukakan bahwa syarat bagi perusahaan yang wajib mengeluarkan zakat saham adalah perusahaan tersebut merupakan perusahaan yang melakukan kegiatan dagang, baik semi industri maupun tidak. Saham dihitung berdasarkan harga sekarang dengan melakukan pemotongan dari harga gedung serta peralatan yang dimiliki oleh perusahaan.

Menurut Syeikh ini, hotel, kendaraan, kereta api, pesawat dan sebagainya, tidaklah wajib zakat, baik atas 
modal maupun keuntungan sekaligus sebagaimana harta perdagangan, maupun atas pendapatan dan pemasukannya saja seperti hasil pertanian (kecuali apabila masih ada sisa dan mencapai satu tahun). Atas dasar ini maka beliau membedakan perusahaan perindustrian (perusahaan yang tidak melakukan kegiatan perdagangan) dengan perusahaan lainnya.

Menurut Yusuf Qardhawi, Ketentuan seperti ini jelas bertentangan dengan keadilan hukum (syariat), karena syariat tidak membedakan dua hal yang sama. Di mana saham yang dikeluarkan dari perusahaan industri murni tidak terkena kewajiban zakat selama-lamanya, baik atas saham maupun atas keuntungan yang diperolehnya, sedangkan saham yang dikeluarkan dari perusahaan perdagangan ataupun industri-perdagangan maka akan terkena kewajiban zakat setiap tahun, baik atas saham maupun keuntungan dari saham itu.

Dalam "Fiqh al-Zakah", sebagaimana yang telah disebutkan dalam pembahasan "zakat investasi gedung, pabrik, dan lainnya", Yusuf Qardhawi mengemukakan tiga pendapat yaitu: 1) Pendapat yang menyamakan gedung dan pabrik dengan harta perdagangan, karena itu harus dinilai (dihitung) harganya tiap tahun dan dikeluarkan zakatnya sebesar $2.5 \%$. 2) Pendapat yang menegaskan bahwa zakatnya diambil dari pendapatan dan keuntunganya, dengan alasan bahwa ia termasuk kekayaan yang bersifat penggunaan. Oleh karena itu maka zakatnya dipungut sesuai ketentuan zakat uang. 3) Pendapat yang menyamakannya dengan tanah pertanian, dengan demikian harus dikeluarkan zakatnya $10 \%$ atau $5 \%$ atas pendapatan bersih.

Menurut Yusuf Qardhawi, membedakan perusahaan-perusahaan industri atau semi industri dengan perusahaan dagang atau semi dagang, di mana yang pertama dibebaskan dari zakat, sedangkan yang kedua tidak, ini merupakan pembedaan yang tidak berdasar pada al-Qur'an, hadis, ijma' dan qiyas yang benar. Menurutnya, hal tersebut dapat dianalogikan pada zakat pabrik dan gedung yang dianalogikan dengan zakat pertanian dan harus dikeluarkan zakatnya $10 \%$ atau $5 \%$ dari pendapatan bersih.

Tidak ada landasan yang mengemukakan bahwa saham yang dikeluarkan dari perusahaan dagang diwajibkan zakat sedangkan yang dikeluarkan oleh perusahaan industri tidak wajib zakat, karena kedua perusahaan tersebut sama-sama merupakan modal yang tumbuh dan berkembang yang memberikan keuntungan tahunan yang terus mengalir, bahkan bisa jadi perusahaan industri memperoleh keuntungan yang lebih besar.

Menurut pemikiran Yusuf Qardhawi, jika diambil dari pendapat yang melihat saham sesuai dengan jenis perusahaan dagangnya, di mana saham merupakan bagian dari modal perusahaan, maka ia lebih cenderung menyamakan perusahaan-perusahaan itu (apa pun jenisnya) layaknya individu-individu. Perusahaan-perusahaan industri atau semi industri yang dimaksudkan adalah perusahaan-perusahaan yang modalnya terletak dalam perlengkapan, alat-alat, gedung-gedung, dan perabot, seperti percetakan, pabrik, hotel, kendaraan angkutan, taksi dan lain-lain zakatnya tidak diambil dari saham-sahamnya, namun diambil dari keuntungan bersihnya sebesar $10 \%$.

Sedangkan perusahaan perdagangan, yaitu perusahaan yang kebanyakan modalnya terletak dalam bentuk barang yang diperjual-belikan dan materinya tidak tetap, maka zakatnya diambil dari sahamnya, sesuai dengan harga yang berlaku di pasar, ditambah dengan keuntungannya. Oleh karena itu, zakatnya sekitar $2.5 \%$, setelah nilai peralatan yang masuk dalam saham, dikeluarkan. Hal ini sesuai dengan pendapat beliau mengenai harta perdagangan yaitu, bahwa zakatnya wajib atas modal yang bergerak. Perlakuan terhadap perusahaan-perusahaan dagang ini sama dengan perlakuan terhadap toko-toko dagang yang dimiliki perorangan.

Mengenai obligasi, YusufQardhawi mengatakan bahwa obligasi adalah semacam cek berisi pengakuan bahwa bank, perusahaan, atau pemerintah berhutang kepada pembawanya sejumlah tertentu dengan bunga tertentu pula. Maka, pemilik obligasi sesungguhnya pemilik piutang yang ditangguhkan pembayaranya, tetapi hutang itu harus segera dibayar bila tiba masa pembayaranya. Dari sini, maka obligasi wajib dikeluarkan zakatnya apabila obligasi itu sudah berada di tangan selama satu tahun atau lebih, demikian pendapat yang dipaparkan imam Malik dan Abu Yusuf.

Akan tetapi jika belum sampai waktu pembayarannya, maka tidak wajib dibayarkan zakatnya, karena ia merupakan piutang yang tertangguhkan. Begitu juga apabila belum cukup setahun dalam pemilikannya, maka tidak wajib dikeluarkan zakatnya karena zakat wajib apabila sudah berlalu satu tahun.

Menurut Yusuf Qardhawi, sebagaimana yang telah dijelaskan pada pembahasan sebelumnya, bahwa pendapat yang benar tentang piutang yang mungkin dapat kembali (piutang yang ada di tangan orang yang mampu membayarnya), wajib dikeluarkan zakatnya setiap tahun. Alasanya, karena piutang yang mungkin dapat kembali itudianggap sesuatu yang 
berada dalam pemilikan orang itu. Hal ini sesuai dengan pendapat mayoritas ulama fikih seperti $\mathrm{Abu}$ Ubaid dan lainnya.

Menurutnya, pendapat ini hanya bisa diterapkan pada obligasi saja karena ia merupakan piutang yang memiliki ciri khusus yang berbeda dengan piutangpiutang yang selama ini diketahui oleh para ahli fikih. Meskipun bunga ini hukumnya haram namun karena piutang ini berkembang dan memberi keuntungan (bunga) kepada pemiliknya maka pemilik obligasi tetap memiliki kewajiban untuk mengeluarkan zakat obligasinya. Karena haramnya bunga tidak menjadi alasan untuk membebaskan pemilik obligasi dari zakat, sebab mengerjakan perbuatan terlarang tidak memberikan keistimewaan kepada yang mengerjakannya. Oleh karena itu, para ahli fikih sepakat akan wajibnya zakat atas perhiasan yang diharamkan, sedangkan mereka berbeda pendapat tentang kewajiban zakat atas perhiasan yang mubah.

Obligasi yang mendatangkan bunga, sebagaimana deposito berbunga itu wajib dikeluarkan zakatnya seperti zakat perdagangan yaitu sebesar $2.5 \%$. Sedangkan bunga yang diperoleh darinya tidak wajib dizakati, sebab ia merupakan harta tidak halal. Oleh karena itu maka seorang muslim tidak boleh memanfaatkannya, tetapi menginfakkanya untuk halhal kebaikan dan kemaslahatan umum, selain untuk pembangunan masjid, pencetakan mushaf, dan syi' arsyiar agama lainnya.

Pendapat kedua: Pendapat yang memandang bahwa saham sama dengan barang dagang dan tidak membedakan jenis perusahaan yang mengeluarkan saham.

Ulama besar seperti Abu Zahra, Abdur Rahman Hasan, dan Abdul Wahab Khallaf berpendapat bahwa saham dan obligasi adalah kekayaan yang diperjual-belikan, karena pemiliknya memperjualbelikan saham dan obligasi dan dari kegiatan jualbeli tersebut pemilik memperoleh keuntungan sama seperti seorang penjual dengan barang dagangannya. Berdasarkan pandangan tersebut, maka saham dan obligasi termasuk objek zakat seperti kekayaan-kekayaan dagang lain dan dinilai sama dengan barang dagangan.

Hal itu berarti bahwa zakat dipungut pada tiap akhir tahun sebesar $2.5 \%$ dari nilai saham sesuai dengan harga pasar pada saat itu dan setelah ditambah dengan keuntungan, dengan syarat pokok dan keuntungannya itu cukup senisab atau ditambah dengan keuntungan dari sumber lain yang cukup senisab.
Berbeda dengan pendapat pertama yang membedakan antara saham pada satu perusahaan dengan perusahaan lainnya, di mana sebagian zakatnya dipungut dari keuntungan, sedangkan yang lain diambil dari saham dan keuntungannya. Sesungguhnya hal seperti ini sangat menyulitkan, apalagi bagi orang yang minim pengetahuan agama namun memiliki banyak saham dan obligasi di beberapa perusahaan.

Syeikh Abdul Aziz bin Abdullah bin Baz dalam bukunya yang berjudul "Tanya Jawab Tentang Rukun Islam" menyatakan bahwa pemilik saham yang disiapkan untuk perdagangan, diwajibkan mengeluarkan zakatnya jika telah mencapai satu tahun, sama seperti tanah, mobil, dan sebagainya yang disiapkan untuk dagang. Namun, jika saham-saham tersebut merupakan barang untuk disewa dan bukan untuk dijual seperti tanah, mobil, maka itu semua tidak wajib zakat. Zakat itu wajib pada barang yang disewa jika telah genap setahun dan telah mencapai nishab sebagaimana barang lainnya.

Menurut Yusuf Qardhawi, saham dapat dikeluarkan zakatnya dengan dua ketentuan yaitu: 1) Jika sahamnya dijadikan sebagai objek jual-beli (barang dagangan) maka zakat yang wajib dikeluarkan sebesar $2.5 \%$ dari harga saham di pasar, yaitu harga pada hari wajibnya zakat, sebagaimana barang-barang dagangan. 2) Jika saham itu diambil keuntungan tahunannya, maka zakatnya sebagai berikut: a) Jika pemilik saham bisa mengetahui, baik melalui perusahaan maupun lainya, nilai atau jumlah kekayaan perusahaan yang direpresentasikan oleh sahamnya, maka dia mengeluarkan zakatnya sebesar $2.5 \%$. b) Jika dia tidak mengetahuinya, maka para ulama berbeda pendapat yaitu: mayoritas ulama berpendapat bahwa pemilik saham menggabungkan keuntungan saham itu dengan hartanya yang lain, jika sudah lewat satu tahun dan mencapai satu nisab maka dia mengeluarkan zakatnya sebesar $2.5 \%$ sedangkan ulama lain berpendapat bahwa dia mengeluarkan zakat sebesar $10 \%$ dari keuntungan sahamnya, langsung setelah keuntungan itu didapat. Hal ini diqiyaskan dengan zakat pertanian.

Golongan Syafi'iyah, Hanafiyah dan Malikiyah mewajibkan pungutan zakat pada uang kertas dan surat-surat berharga lainnya karena uang kertas, rekening bank dan surat-surat berharga lainnya disamakan dengan emas dan perak, karena sama-sama memiliki fungsi sebagai alat tukar menukar barang dan merupakan harta benda yang bernilai ekonomis dan berkembang, yaitu mengandung unsur maliyah dan unsur nama'l istinma'. Sedangkan menurut golongan 
Hanabilah, tidak wajib zakat pada harta tersebut karena bukan merupakan emas dan perak, sedangkan yang diwajibkan zakat adalah emas dan perak.

Menurut Yusuf Qardhawi zakat obligasi dapat dianalogikan dengan zakat perdagangan yaitu sebesar $2,5 \%$ dan zakatnya baru dapat dikeluarkan setelah obligasi tersebut berada di tangannya selama satu tahun, dan jika belum mencapai satu tahun maka tidak dipungut zakatnya.

Selain beberapa ushŭl yang telah dijelaskan sebelumnya, Alasan lain Yusuf Qadhawi mewajibkan zakat atas saham dan obligasi adalah karena menurutnya saham dan obligasi merupakan jenis harta kekayaan dimana pada setiap harta terdapat hak bagi orang lain yang berupa zakat, infaq dan sedekah. Yusuf Qardhawi juga mewajibkan zakat atas semua jenis harta yang berkembang baik dengan sendirinya maupun dengan pengelolaan sebagaimana saham dan obligasi. Selain itu dari kedua benda tersebut samasama memiliki nilai ekonomi. Disamping bernilai ekonomi, saham dan obligasi merupakan harta yang dapat memberikan pemasukan yang cukup tinggi jika dibandingkan dengan pertanian atau perdagangan. Sehingga menurutnya kedua benda tersebut merupakan sumber zakat yang wajib dikeluarkan zakatnya.

\section{KESIMPULAN DAN SARAN}

\section{Kesimpulan}

Dari beberapa uraian yang telah dipaparkan di atas, dapat penulis simpulkan Bahwasanya sumbersumber zakat yang tercantum dalam al-Qur'an masih menimbulkan banyak perbedaan pendapat seperti:

Golongan Syafi'iyah, Hanafiyah dan Malikiyah mewajibkan pungutan zakat pada uang kertas dan surat-surat berharga lainnya karena uang kertas, rekening bank dan surat-surat berharga lainnya disamakan dengan emas dan perak karena sama-sama memiliki fungsi sebagai alat tukar menukar barang. Sedangkan menurut golongan Hanabilah, barangbarang tersebut tidak wajib dikeluarkan zakatnya karena bukan merupakan emas dan perak.

Yusuf Qardhawi menyatakan bahwa barang yang wajib dizakati adalah barang yang berkembang dan dapat menghasilkan pemasukan sehingga menurutnya saham dan obligasi termasuk sumber zakat. Menurutnya pabrik dan gedung dapat dianalogikan dengan tanah pertanian, maka harus dikeluarkan zakatnya $10 \%$ atau $5 \%$ dari pendapatan bersih. Perusahaan-perusahaan industri atau semi industri adalah perusahaan-perusahaan yang modalnya terletak pada perlengkapan, alat-alat, gedung-gedung, dan perabot, seperti: perusahaan percetakan, pabrik, hotel, kendaraan angkutan, taksi dan lain-lain tidaklah dipungut zakat dari saham-sahamnya, namun dari keuntungan bersihnya sebesar $10 \%$.

Sedangkanperusahaan-perusahaanperdagangan, yaitu perusahaan yang kebanyakan modalnya terletak dalam bentuk barang yang diperjual-belikan dan materinya tidak tetap, maka zakatnya diambil dari sahamnya, sesuai dengan harga yang berlaku di pasar, ditambah dengan keuntungannya. Oleh karena itu, zakatnya sekitar $2.5 \%$, setelah nilai peralatan yang masuk dalam saham, dikeluarkan. Hal ini sesuai dengan pendapat Yusuf Qardhawi mengenai harta perdagangan yaitu, bahwa zakatnya wajib atas modal yang bergerak.

Sedangkan mengenai zakat obligasi menurut Yusuf Qardhawi wajib dikeluarkan zakatnya apabila obligasi itu sudah berada di tangan pemilik selama satu tahun atau lebih. Obligasi yang mendatangkan bunga, sebagaimana deposito berbunga itu wajib dikeluarkan zakatnya seperti zakat perdagangan, yaitu sebesar $2.5 \%$. Sedangkan bunga yang diperoleh darinya tidak wajib dizakati, sebab ia merupakan harta tidak halal.

\section{Saran}

Dari hasil penelitian ini mengenai pemikiran Yusuf Qardhawi mengenai pengeluaran zakat atas saham dan obligasi, peneliti dapat memberi masukan dan saran agar dikeluarkan zakat atas saham dan obligasi yang diperdagangkan atau dimiliki oleh perusahaanperusahaan, khususnya di Indonesia, karena saham dan obligasi termasuk barang yang berkembang dan dapat menghasilkan pemasukan. Perusahaan yang memiliki saham dan obligasi dapat menghitung zakat yang dikeluarkan dengan mengaplikasikan pendapat Yusuf Qrdhawo maupun pendapat ulama lain, yang dirasa sesuai dengan karakteristik perusahaannya, serta saham dan obligasi yang dikeluarkan perusahaan tersebut. Selain itu, kewajiban zakat atas saham dan obligasi juga telah disepakati oleh para ulama, baik ulama golongan pertama maupun ulama-ulama besar dan kontemporer.

\section{DAFTAR RUJUKAN}

Abdillah Muhammad bin Ismail al-Bukhori, Imam Abi. t.th. Matan Al-Bukhori. Libanon: Maktab Al Bahun Wa Dirasat.

Abdullah al-Mushlih dan Shalah Ash-Shawi. 2008. "Ma La Yasa' at-Tajira Jahluhu". Terjemahan AbuatUmart|Basyir. Fikih Ekonomi Keuangan Islom 2008. Jakarta: Ppetftaq. 
Aibak, Kutbuddin. 2006. Kajian Fiqh Kontemporer. Surabaya: eLKAF.

Al-Qardhawi Yusuf. 2007. Fiqh al-Zakah. Beirut: Muassasah al-Risalah.

2007. "Fiqh al-Zakah". Terjemahkan Salman Harun, Didin Hafidhuddin, dan Hasanuddin. Hukum Zakat: Studi Komparatif Mengenai Status dan Filsafat Zakat Berdasarkan Qur'an dan Hadits. Cet. X; Bogor: Pustaka Litera Antar Nusa.

. 2005. "Dauru Al-Zakat: Fi Ilaaj Al-Musykilaat Al-Iqtishaadiyah. Terjemahan Sari Narulita. Spektrum Zakat. Jakarta: Zikrul Hakim.

Al-Zuhayly, Wahbah. 2006. Al-Fiqh Al-Islami Wa Adillatuh. Damaskus: Darul Fikr.

Ali Hasan, M. 1997. Tuntunan Puasa dan Zakat. Jakarta: PT Raja Grafindo Persada. 2006. Zakat dan Infak: Salah Satu Solusi Mengatasi Problema Sosial di Indonesia. Jakarta: Kencana.

Ash-Shofa, Burhan. 2004. Metode Penelitian Hukum. Jakarta: PT Rineka Cipta.

Aziz bin Abdullah bin Baz, Syeikh Abdul. 2003. "Tuhfatul Ikhwan bi Ajwibatin Muhammatin Tata'allaqu bi Arkanil Islam". Terjemahan Mudzakir Muhammad Arif. Tanya-jawab Tentang Rukun Islam (t. t. t.p).

Aziz Muhammad Azzam, Abdul dan Abdul Wahhab Sayyed Hawwes. 2009. "Al-Wasith Fi Fiqh AlIbadah”. Terjemahkan Kamran As'at Irsyadi. Fiqh Ibadah. Jakarta: AMZAH.

Dahlan, Abdul Aziz. 2003. Ensiklopedi Hukum Islam. Cet. VI; Jakarta: PT Ichtiar Baru Van Hoeve.

Departemen Agama RI. 2005. Mushaf al-Qur'an Terjemah. Jakarta: al Huda.

Fakhruddin .2008. Fiqh dan Manajemen Zakat di Indonesia. Malang: UIN-Malang Press.

Hadi Permono, Syekhul. 1992. Sumber-Sumber Penggalian Zakat. Jakarta: Pustaka Firdaus.

Hafidhuddin, Didin. 2004. Zakat dalam Perekonomian Modern. Jakarta: Gema Insani Press.

2008. Panduan Praktis tentang

Zakat, Infaq, dan Sedekah. Cet. VIII; Jakarta: Gema Insani Press.

2008. The Power of Zakat: Studi

Perbandingan Pengelolaan Zakat Asia Tenggara. Malang: UIN-Malang Press. 2007. Agar Harta Berkah dan Bertambah. Jakarta: Gema Insani Press.

Hasan Ali bin Halaf bin Abdul Malik, Abi. 2004.
Syarah Shahih al-Bukhori. Riyadh: Maktabah al-Rush Nasyirun.

Hasbi Ash Shiddieqy, T. M. 2006. Pedoman Zakat. Cet. X; Semarang: PT Pustaka Rizki Putra.

Hidayatullah, Syarif. 2008. Ensiklopedia Rukun Islam Ibadah Tanpa Khilafiah: Zakat. Jakarta: Al-Kautsar Prima.

Huda, Nurul dan Musthafa Edwin Nasution. 2007. Investasi pada Pasar Modal Syari'ah. Jakarta: Kencana.

Husain bin Hajjaj, Imam Abi. 1998. Shahih Muslim. Libanon: Alimul Kutubi.

Ibrahim Al-Syaikh, Yasin. 2004. Zakat Membersihkan Kekayaan, Menyempurnakan Puasa Ramadha. Bandung: Penerbit Marja.

Inoed, Amiruddin. dkk. 2005. Anatomi Fikih Zakat: Potret dan Pemahaman Badan Amil Zakat Sumatera Selatan. Yogyakarta: Pustaka Pelajar.

Isa Muhammad bin Isa bin Saurah, Abi. t.th. Sunan al-Turmudzi. t.tp: Dar al-Fikr.

Mahmud Marzuki, Peter. 2009. Penelitian Hukum. Jakarta: Kencana.

Moeloeng, Lexy. 2006. Metodologi Penelitian Kualitatif. Bandung: PT Remaja Rosdakarya.

Saifullah. 2006. Buku Panduan Metodologi. Malang: Fakultas Syari'ah UIN Malang.

Soekanto, Soerjono. 1984. Pengantar Penelitian Hukum. Jakarta: Universitas Indonesia.

Sudirman. 2007. Zakat dalam Pusaran Arus Modernitas. Malang; UIN-Malang Press. . 2005. "Yusuf Al-Qardhawi: Pembaharu Fiqh Islam Kontemporer". El-Qist; Jurnal Ilmiyah Fakultas Syari'ah. Malang: Fakultas Syari'ah.

Sugiono. 2008. Metode Penelitian Kuantitatif Kualitatif dan R\&D. Bandung: ALVABETA.

Sukandarrumidi. 2006. Metodologi Penelitian: Petunjuk Praktis untuk Peneliti Pemula. Yogyakarta: Gadjah Mada University Press.

Sulaiman bin Ats-ats al-Sajastani, Imam al-Hafidz. 2002. Shahih Sunan Abi Dawud. Kuwait: Gharas.

Sulaiman bin Shalih al-Qurasyi. 2003. "AlQaradhawiy Fiil Miizaan". Terjemahan M. Abdul Ghoffar. Pemikiran Yusufal-Qaradhaawiy dalam Timbangan. Bogor: Pustaka Imam AsySyafi'i.

Suryabrata, Sumadi. 2005. Metodologi Penelitian. Jakarta: PT Raja Grafindo Persada.

Taqyuddin an-Nabhani. 1996. Membangun Sistem Ekonomi Alternatif: Perspektif Islam. Surabaya: 
Risalah Gusti.

Talimah, Ishom. 2001. "Al-Qardhawwiy Faqiihan”. Terjemahkan Samson Rahman. Manhaj Fikih Yusuf Al-Qaradhawi. Jakarta: Al-Kautsar.

Taswan. 2006. Manajemen Perbankan: Konsep Tekhnik dan Aplikasi. Cet. I; Yogyakarta: UPP STIM YKPN.

Yafie, Ali. 1995. Menggagas Fiqih Sosial: Dari Soal Lingkungan Hidup Asuransi Hingga Ukhuwah, Cet. III; Bandung: Mizan. 